\title{
PENGARUH KECERDASAN INTERPERSONAL, GAYA BELAJAR DAN MOTIVASI BERPRESTASI TERHADAP HASIL BELAJAR PENDIDIKAN AGAMA ISLAM KELAS XI SMAN 1 TINAMBUNG
}

\author{
Nur intan purnamasari \\ Uin Alauddin Makassar
}

\begin{abstract}
This research aims to find out the influence of interpersonal shrewdness, learning style, and motivation achievement toward pai learning result of SMA 1 tinambung' $s$ students in class XI. This research is ex-post facto research. The population of this research is all of students class XI in SMA 1 tinambung. The sampling of this research used simple random sampling technique. The results of this reasearcch showed that (1) interpersonal shrewdness influenced PAI learning result significantly which was proved by sign value $<=0,05(0,000<0,05)$ meanas that HO didint approved and HI was accepted (2) learning style didn't influence PAI learning result significantly of students class XI in SMA 1 Tinambung (3) motivation achievement didn't influence significantly Pai learning result, which is proved by sign value $(0,031>0,05)$ means that $\mathrm{HO}$ is accepted while $\mathrm{H} 1$ was rejected. (4) there was significant effect of interpersonal shrewdness simultaneously, learning style and motivation achievement toward PAI's learning result which was proved by sign value 0,05 $(0,000<0,05)$.
\end{abstract}

Keywords: Interpersonal shrewdness, learning style, and motivation achievement

\section{PENDAHULUAN}

Kecerdasan atau kemampuan mental adalah satu dari banyaknya anugerah dari Tuhan kepada manusia lalu membuatnya menjadi salah satu kelebihan manusia dibandingkan dengan makhluk ciptaan Tuhan lainnya, dengan kecerdasan yang dimilikinya manusia dapat terus mengembangkan kemampuan dan bakat yang semakin kompleks melalui proses belajar dan berpikir terus menerus dalam hal ini tenaga pendidiklah yang mempunyai peranan yang besar dan strategis terhadap perkembangan kecerdasan peserta didik.

Guru sebagai pendidik atau penyelenggara pendidikan berkewajiban mengetahui kemampuan dan tingkat kecerdasan yang berbeda pada setiap peserta didiknya melalui pengalaman dan pengamatan ketika melaksanakan proses pembelajaran. Tolok ukur dalam Pembelajaran Pendidikan Agama Islam, peserta didik diharapkan dapat berinteraksi dengan peserta didik lain dalam proses pembelajaran. Pembelajaran Agama Islam adalah salah satu ilmu dasar yang memiliki berperan dalam kehidupan sehari-hari yang dapat mendukung kemajuan ilmu pengetahuan dan teknologi sekarang ini, yang juga berhubungan dengan konsep interaksi sosial dengan orang lain, dalam hal ini biasa disebut kecerdasan interpersonal.

Kecerdasan interpersonal adalah penggambaran dari konsep interaksi dengan orang lain di sekitarnya. Interaksi yang dimaksudkan bukan sekedar interaksi biasa saja seperti 
berdiskusi dan membagi suka ataupun duka, tetapi berusaha memahami pikiran, perasaan dan kemampuan demi membagi empati atau respon. Biasanya atau dominan seorang yang memiliki kecerdasan interpersonal yang tinggi lebih sering berada pada kelompok ekstrovert dan sangatlah peka terhadaap perasaan orang lain. Menyadari dan memahami karakter serta membangun komunikasi dengan orang lain juga menjadi salah satu faktor keberhasilan belajar.

Kelancaran atau keberhasilan proses belajar tentunya akan diadaptasi oleh berbagai faktor baik dalam lingkup sekolah, keluarga, ataupun dari peserta didik itu sendiri. Peserta didik sebagai orang yang sedang belajar dan berkembang memiliki karakter dan keunikan masing-masing dalam proses pembelajaran. karakter yang dimiliki membuat peserta didik memiliki respon yang berbeda dalam memehami suatu pembelajaran yang dapat berpengaruh terhadap keberhasilan belajarnya. Karakteristik peserta didik yang dimaksud dalam penelitian ini adalah gaya belajar, menjelaskan bagaimana individu belajar atau cara yang dilakukan oleh setiap orang untuk mencari konsentrasinya pada proses penguasaan informasi yang sulit dan baru melaui persepsi yang berbeda. Ada peserta didik yang cenderung lebih mudah menyerap informasi lebih melalui indera pengelihatan (visual), ada juga yang melalui indera pendengaran (auditori), dan melalui aktivitas fisik dan tubuh (kinestetik).

Setiap peserta didik dipastikan mempunyai kelebihan maupun kekurangan masingmasing. Akan lebih mudah jika saja kekurangannya dapat diketahui dan dapat diterima sebagaimana adanya, sementara kelebihannya diperhatikan dan dikembangkan lebih baik, maka akan mendorong individu itu berprestasi dengan optimal dan maksimal atau paling tidak, optimal sesuai dengan kemampuannya masing-masing. Kelebihan dan kekurangan inilah yang seringkali disebut dengan keunikan individu, yang membedakan individu yang satu dengan yang lain.

Peran motivasi jangan diremehkan dalam pembelajar, karena motivasi belajar memberikan rangsangan, semangat dan perasaan senang dalam kegiatan belajar, peserta didik yang memiliki motivasi yang lebih akan memiliki banyak energy dalam melakukan kegiatan belajar. Motivasi belajar ditimbulkan karena dorongan dan minat peserta didik untuk berprestasi.

Pendidikan Agama Islam sebagai salah satu ilmu dasar yang seharusnya dalam proses pembelajarannya dapat mengembangkan pendidikan Islam, yang seiringan dengan berkembangnya ilmu pengetahuan dan teknologi, sehingga perkembangan ilmu pengetahuan dan teknologi ikut memacu perkembangan pendidikan agama islam itu sendiri, untuk itu pemahaman peserta didik dalam pembelajaran PAI sangat penting, karena merupakan landasan untuk memahami ilmu pengetahuan dan teknologi pada tingkatan selanjutnya.

Sesuai dengan Observasi awal yang telah dilakukan pada SMA Negeri 1 Tinambung, peneliti menemukan peserta didik memiliki masalah kesulitan belajar dan rendahnya hasil belajar dilihat dari hasil belajar peserta didik masih terdapat beberapa 
yang memiliki nilai rendah di bawah KKM, yang dibuktikan dengan melihat nilai raport peserta didik yang berbentuk data dari 126 orang peserta didik $35 \%$ atau 43 diantaranya memperoleh nilai yang masih di bawah KKM, peneliti juga melakukan wawancara, dengan wali kelas untuk memperkuat informasi yang telah didapatkan oleh peneliti, hal ini juga disebabkan karna banyak banyak peserta didik yang tidak dapat mengembangkan kecerdasan yang mereka miliki seperti kurangnya interaksi antar teman dan guru sehingga peserta didik kurang aktif dalam memberikan pendapat serta memberi ide-ide mereka dalam pemecahan masalah, sementara Pendidikan Agama Islam merupakan mata pelajaran yang memerlukan kecerdasan interpersonal, dan motivasi yang baik antara peserta didik, guru dan masyarakat untuk menunjang ketercapaian tujuan pembelajaran. Atas dasar itulah sehingga peneliti merasa perlu melakukan penelitian "Pengaruh kecerdasan interpersonal, gaya belajar dan motivasi berprestasi terhadap hasil belajar Pendidikan Agama Islam peserta didik kelas XI SMA Negeri 1 Tinambung Polewali Mandar." Bertujuan untuk mengetahui pengaruh kecerdasan interpersonal, gaya belajar dan motivasi berprestasi terhadap hasil belajar peserta didik kelas XI SMAN 1 Tinambung.

\section{METODE PENELITIAN}

Penelitian ini menerangkan mengenai pengaruh antara kcerdasan interpersonal, gaya belajar, motivasi berprestasi, dan hasil belajar PAI peserta didik. jenis penelitian ini adalah merupakan penelitian ex-post facto yang bersifat kausalitaas. Artinya, penelitian dilakukan tanpa memberi perlakuan karena perlakukan varibel sudah terjadi sebelumnya.

Penelitian ini diprioritaskan pada pembelajaran Agama Islam di SMAN 1 Tinambung.Lokasi penelitian di SMAN 1 Tinambung Polewali Mandar. Metode pengumpulan data yang digunakan pada penelitian ini yaitu: angket (koesioner), observasi (observation), juga dokumentasi (documentation). Intrumen penelitian adalah Angket kecerdasan interpersonal, gaya belajar dan motivasi berprestasi, pedoman obsevasi, dan dokumentasi, sedangkan teknik analisis data adalah statistik deskriptif dan statistik inferensial dengan menggunakan regresi linear sederhana dan regresi linear berganda.

\section{KAJIAN TEORI}

\section{A. Pengaruh Kecerdasan Interpersonal Terhadap Hasiil Belajar PAI Peserta didik}

Terdapat beberapaa faktor-faktorr yang dapat mempengaruhi hasil belajar peserta didik baik yang berasal dari dalam diri peserta didik (eksternal) maupun diluar diri peserta didik (internal). Faktor dari dalam diri peserta didik yang tiidak kalah pentingnya dalam mencapai keberhasilan peserta didik adalah faktor inteligensi/kecerdasan.Faktor inteligensi/kecerdasan juga sangat berpengaruh dalam memahami pelajaran.

Pada dasarnya setia peserta didik memiliki kecerdasan yang tentunya berbeda satu sama lainnya. Sama halnya dengan kecerdasan interpersonal, setiap peserta didik pasti 
memiliki kecerdasan interpersonal, yang membedakan hanya kondisi-kondisi yang mempengaruhi, sehingga perkembangannya kecerdasan interpersonalnya terhambat. Peserta didik yang cerdas dalam berkehidupan sosial merupakan aset untuk mengembangkan banyak hal dalam dirinya dan membuatnya bisa menyimpulkan faktafakta dan menganalisisnya dengan baik.

Kecerdasan interpersonal merupakan kecerdasan yang sangat diperlukan untuk berprestasi. Kecerdasan interpersonal peserta didik yang baik pasti akan menciptakan/melahirkan suasaana atau lingkungan belajar yang baiik pula, komunikasi antara peserta didik dan hubungan peserta didik dengan pendidik menjadi lebih dekat dan akrab, serta dapat mendorong peserta didik aktif dalam kegiatan belajar mengajar karena peserta didik merasa nyaman dan merasa percaya diri dalam kegiataan pembelajaran. Suasana belajar menjadi baik, akan membuat peserta didik lebih aktif hingga menimbulkan suasana belajar menjadi menyenangkan, dan membuat suasana hatinya nyaman pada suatu pembelajaran. Hendaknya setiap peserta didik mempunyai kecerdasan interpersonal yang baik, sehingga akan menciptakan suasana lingkungan kelas yang baik, kedekatan guru dengan murid, keaktifan peserta didik dan hal ini akn menbantu peserta didik dalam mencapai hasil belajarnya yang baik.

Berdasarkan pemaparan diatas, maka ditarik suatu kesimpulan bahwa kecerdasan interpersonal merupakaan faktor pendukung yang sangat penting dalam meraih prestasi atau hasil belajar Pendidikan Agama Islam yang baik bagi peserta didik. Peserta didik yang memiliki tingkat kecerdasan yang tinggi dapat membantu peserta didik untuk memperoleh hasil belajar yang tinggi.

\section{B. Pengaruh Motivasi berprestasi Terhadap Hasil Belajaar PAI}

Motivasi berprestasi akan memberikan dorongan, kekuatan dan tindakan kepada peserta didik. Peserta didik yang mengalami kecemasan, khawatir akan kemampuan mereka untuk menjawab soal dan menyelesaikan tugas PAI mengakibatkan menurunnya motivasi. Dengan memiliki motivasi, hidup peserta didik akan lebih terarah dan mempunyai dorongan atau kemauan. Impuls-impuls pemikiran peserta didik secara pasti akan dipengaruhi oleh keyakinannya, keyakinan tentang kebenaran diri peserta didik sebenarnya, motivasi tentang keinginan dan impiannya, keyakinan tentang sasaran dan tujuannya, keyakinan tentang masa depan sukses peserta didik, dan juga keyakinan dalam mencapai hasil belajar.

Berdasarkan uraian di atas, dapat disimpullkan bahawa motivasi berprestasi akan mempunyai pengaruh atau hubungan terhadap hasil belajar PAI peserta didik. Karena motivasi berprestasi merupakan faktor pendukung yang sangat penting dalam meraih hasil belajar PAI yang baik peserta didik. Peserta didik yang memiliki motivasi berprestasi yang tinggi dapat membantu memperoleh hasil belajar yang tinggi. 


\section{HASIL PENELITIAN DAN PEMBAHASAN}

\section{Pengaruh Kecerdasan Interpersonal Terhadap Hasil Belajar PAI}

Kecerdasan interpersonal merupakan kemampuan untuk mempersepsi dan membedakan suasana hati, maksud, motivasi, dan keinginan orang lain, serta kemampuan memberikan respons secara tepat terhadap suasana hati, temperamen, motivasi dan keinginan orang lain. Kecerdasan interpersonal memungkinkan peserta didik untuk dapat memahami dan berkomunikasi dengan temannya yang lain, melihat perbedaan mood, temperamen, motivasi dan kemampuan. Termasuk kemampuan untuk membentuk dan menjaga hubungan, serta mengetahui berbagai peranan yang terdapat dalam suatu kelompok, baik sebagai anggota maupun pemimpin. Hasil belajar adalah hasil yang diperoleh dan dimiliki setelah melibatkan dirinya secara aktif, baik dari segi fisik maupun mental dalam menyelesaikan masalah. Evaluasi pembelajaran merupakan alat untuk menentukan apakah tujuan pendidikan dan apakah proses dalam pengembangan ilmu pengetahuan telah berada dijalan yang diharapkan.

\begin{tabular}{|l|c|l|l|}
\hline \multicolumn{1}{|c|}{ Variabel } & $\begin{array}{c}\text { Koef.Regresi } \\
\text { (B) }\end{array}$ & t hitung & Sig.t \\
\hline Konstanta & 21.508 & 3.436 & 0.001 \\
\hline $\begin{array}{l}\text { Kecerdasan } \\
\text { Interpersonal } \\
\text { X1) }\end{array}$ & 0,614 & 6.200 & 0.000 \\
\hline R Square & 0,679 & & \\
\hline
\end{tabular}

Berdasarkan hipotesisi pertama, bahwa Kecerdasan interpersonal (X1) berpengaruh signifikan terhadap hasil belajar PAI (Y). Hal ini ditunjukkan oleh nilai signifikan yang lebih kecil dari 0,05 yaitu $0,000<0,05$ yang mengindikasikan bahwa Kecerdasan Interpersonal berpengaruh signifikan terhadap Hasil belajar.

Hal ini relevan dengan penelitian terdahulu yang dilakukan oleh Fajriani yang menjelaskan bahwa kecerdasan interpersonal berpengaruh signifikan terhadap hasil belajar matematika peserta didik ${ }^{1}$, selain penelitian yang dilakukan oleh fajrani terdapat pula penelitian yang dilakukan oleh Natalia dkk, hasil penelitian mereka menunjukkan bahwa keterampilan komunikasi yang merupakan dimensi dari kecerdasan interpersonal memiliki pengaruh yang signifikan dengan pencapaian akademik peserta didik kelas VIII SMP Negeri di Kota Makassar baik yang berakreditasi A maupun B $^{2}$, sejalan dengan penelitian yang dilakukan oleh Najamuddin ${ }^{3}$ yang menunjukkan adanya pengaruh antara

${ }^{1}$ Fajriani, “ Pengaruh Kecerdasan Interpersonal terhadap Hasil Belajar Matematika Peserta didik kelas X SMAN se- Kab. Bulukumba” Pedagogy vol. 2 no. 1 (2017), h. 71

${ }^{2}$ Natalia Puspita Wulandari dkk, "Pengaruh Kecerdasan Interpersonal, Kemampuan Berfikir dan Efikasi diri terhadap Hasil Belajar Matematika dan Sikap Terhadap Matematika Siswa Kelas VIII di Sekolah Menengah Pertama di Kota Makassar" Variansi UNM (2018),h.68

${ }^{3}$ Najamuddin, " Pengaruh Kecerdasan Interpersonal dan Taks Commiment terhadap Hasil Belajar Siswa Kelas VIII MTSN Balang-balang Kab.Gowa” MaPan vol. 3 no. 2 (2015), h.174 
kecerdasan interpersonal terhadap hasil belajar matematika siswa dengan pengaruh 0,741 dan nilai sig $0,000<0,05$. Hal ini menunjukkan bahwa terdapat pengaruh kecerdasan interpersonal terhadap hasil belajar matematika peserta didik. Kedua variabel ini menunjukkan pengaruh yang searah yang berarti semakin tinggi tingkat kecerdasan interpersonal maka semakin tinggi pula hasil belajar peserta didik, demikian sebaliknya semakin rendah kecerdasan interpersonal maka semakin rendah pula hasil belajar matematika peerta didik ${ }^{4}$.

Kecerdasan interpersonal atau bisa juga dikatakan kecerdasan sosial, diartikan sebagai kemampuan dan keterampilan seseorang dalam menciptakan relasi. Kecerdasan interpersonal menjadi penting karena pada dasarnya manusia tidak bisa hidup sendiri, banyak kegiatan dalam hidup manusia yang saling terikat dengan yang lainnya. Seseorang yang gagal mengembangkan kecerdasan interpersonalnya akan banyak mengalami hambatan dalam dunia sosialnya. Bisa dibayangkan jika seorang peserta didik harus bekerja kelompok dan belajar Pendidikan Agama islam kemudian rasa tidak nyaman menyebabkannya menyingkir dari kegiatan bersama tersebut, hal ini tentu akan sangat merugikan peserta didik yang bersangkutan.

Hasil penelitian oleh Sukdi juga menunjukkan Terdapat hubungan signifikan antara keterampilan sosial (kecerdasan interpersonal) dengan pencapaian akademik peserta didik (hasil belajar). Keterampilan sosial sangat penting dalam proses pembelajaran di sekolah, peserta didik dengan keterampilan sosial yang tinggi memiliki pencapaian akademik yang lebih baik dari peserta didik yang memiliki keterampilan sosial yang kurang.

\section{Pengaruh Gaya Belajar (Visual, Auditori dan Kinestetik Terhadap Hasil Belajar PAI Peserta didik Kelas XI SMAN 1 Tinambung}

Berdasarkan hasil pengujian hipotesis ditemukan perbedaan model pengaruh gaya belajar terhadap hasil belajar PAI kelas XI SMAN 1 Tinambung. Adanya perbedaan hasil belajar PAI ditinjau dari gaya belajar juga mengindikasikan bahwa antara setiap jenis gaya belajar tersebut ada gaya belajar yang lebih baik dari gaya belajar yang lainnya. Sehingga hasil belajar PAI peserta didik akan tinggi tergantung gaya belajar yang dimilikinya.

Gaya belajar visual yang memegang peran penting dalam belajar adalah mata/pengelihatan (visual) peserta didik cenderung belajar berdasarkan apa yang mereka lihat, mereka belajar lebih cepat dengan menggunakan tampilan-tampilan visual, seperti diagram, buku pelajaran bergambar dan video. Mata pelajaran PAI terdiri dari teori dan praktek. Dalam peajaran guru lebih dominan untuk melakukan aktivitas visual dengan mewajibkan peserta didik untuk menyimak hand out atau buku manual yang sudah ditentukan. berdasarkan analisis data dan uji hipotesis yang dilakukan dengan uji regresi linear diperoleh hasil bahwa gaya belajar visual tidak berpengaruh signifikan terhadap hasil belajar PAI peserta didik, ditunjukkan dengan nilai signifikan 0,685, yang berarti jauh lebih besar dari nilai signifikan 0,05. Maka dapat disimpulkan bahwa kontribusi yang 
diberikan gaya belajar visual terhadap hasil belajar pendidikan agama islam tergolong sangat kurang, hal ini disebabkan oleh kurangnya perhatian peserta didik dalam pembelajaran PAI, oleh karena pendidik kurang memberi stimulus terhadap peserta didik dalam menggunakan indra visualnya, misalnya penggunaan media pembelajaran video yang masih kurang maksimal diterapkan dalam pembelajaran, peserta didik cenderung lebih banyak mendengarkan disebabkan metode pembelajaran yang paling sering digunakan dalam pembelajaran PAI di kelas XI SMAN 1 Tinambung adalah metode ceramah, adapun faktor eksternal yang juga mendukung kurangnya pengaruh gaya belajar visual terhadap hasil belajar PAI, yaitu kondisi ruang belajar yang tidak tertutup sepenuhnya sehingga peserta didik cenderung untuk bisa melihat keluar ruangan sehingga peserta didik mejadi tidak fokus dalam mengikuti pembelajaran. Peserta didik akan cenderung tertarik melihat keluar ruangan untuk memenuhi rasa keingintahuannya terhadap kejadian diluar ruang belajar. Penelitian ini sejalan dengan penelitian yang dilakukan oleh Aswar Anas, yang menunjukkan bahwa kurangnya pegaruh gaya belajar visual dibandingkan dengan dua gaya belajar lainnya terhadap hasil belajar matematika peserta didik kelas VII SMP Negeri Kab.Soppeng. ${ }^{4}$

Peserta didik yang dominan memiliki gaya belajar auditorial mengandalkan kesuksesan belajarnya melalui telinga (alat pendengarannya). Peserta didik yang mempunyai gaya belajar auditorial dapat belajar lebih ceat dengan diskusi verbal dan mendengarkan apa yang guru jelaskan. Dalam pembelajaran PAI di SMAN 1 Tiambung salah satu metode yang guru gunakan dalam memberikan penjelasan materi adalah metode ceramah hal ini memudahkan peserta didik yang memiliki gaya belajar auditori. Maka berdasarkan hasil analisis data dan uji hipotesis, gaya belajar auditorial memiliki pengaruh positif yang signifikan terhadap hasil belajar PAI hal ini dibuktikan dengan nilai signifikan 0,002 yang berarti lebih kecil dari 0,05 hal ini menunjukkan bahwa gaya belajar auditorial memiliki pengaruh yang signifikan terhadap hasil belajar dengan derterminasi $\mathrm{R}_{2}$ sebesar $0,158 \%$ atau $15,8 \%$ yang berarti bahwa gaya belajar auditorial berpengaruh $15,8 \%$ terhadap hasil belajar PAI. Oleh karena itu dapat dikatakan bahwa semakin tinggi gaya belajar auditorial yang dimiliki peserta didik maka akan semakin memberikan pegaruh yang signfikan terhadap hasil belajarnya.

Sejalan dengan penelitian yang dilakukan oleh Aisyah Rahman, yang menjelaskan bahwa terdapat pengaruh yang signifikan gaya belajar auditorial terhadap hasil belajar IPS siswa kelas VII di SMPN 1 Peudada yang dibuktikan dengan nilai F hitung $=4.064$ maka $\mathrm{H}_{0}$ ditolak dan $\mathrm{H}_{1}$ diterima artinya gaya belajar auditorial memiliki pengaruh signifikan terhadap hasil belajar IPS, dengan koefisien nilai pengaruh sebesar 4,53\%.

Lain halnya dengan peserta didik yang memiliki gaya belajar kinestetik, Berdasarkan hasil analisis data dan uji hipotesis yang dilakukan diperoleh fakta bahwa

${ }^{4}$ Aswar Anas,Nilam Permatasari Munir " Pengaruh Gaya belajar terhadap Hasil Belajar Siswa Kelas VII SMP Negeri di Kab.Soppeng Tahun ajaran 2013/2014” Prosiding Seminar Nasional vol. 2 no. 1 (2013), h. 238 
gaya belajar kinestetik tidak memiliki pengaruh signifikan terhadap hasil belajar PAI, ditunjukkan dengan nilai signifikan 0,544, yang berarti jauh lebih besar dari nilai signifikan 0,05 hal ini menunjukkan bahwa gaya belajar kinestetik tidak berpengaruh positif terhadap hasil beajar PAI dengan nilai derterminasi $\mathrm{R}_{2}$ sebesar $0,012 \%$ atau $1,2 \%$ yang berarti bahwa gaya belajar kinestetik hanya berpengaruh 1,2\% terhadap hasil belajar. Peserta didik yang memiliki gaya belajar kinestetik belajar melalui bergerak, menyentuh dan melakukan, peserta didik seperti ini tidak tahan untuk duduk berlamalama mendengarkan pelajaran, sementara pada pembelajaran pendidikan agama islam di SMAN 1 Tinambung guru lebih banyak mengharapkan peserta didik untuk mau membaca dan mendengar, selain itu guru pendidikan agama islam di SMAN 1 Tinambung tersebut jarang menerapkan kerja kelompok dalam kegiatan belajar mengajar.

Sejalan dengan penelitian yang dilakukan oleh Alfarisi, yang menunjukkan bahwa tidak terdapat pengaruh signifikan gaya belajar kinestetik terhadap hasil belajar peserta didik pada mata pelajaran produktif. ${ }^{5}$ Namun hasil penelitian ini bertentangan dengan penelitian yang dilakukan oleh Akhmad suyono, yang menunjukkan bahwa gaya belajar kinestetik secara signifikan berpengaruh terhadap hasil belajar peserta didik pada mata pelajaran Akuntansi kelas XI IPS SMAN 3 Tapung 6 . Hal ini dikarenakan pada penelitian Akhmad sugyono gaya belajar merupakan satu strategi yang dilakukan oleh peserta didik dalam belajarnya unuk mencapai tujuan yang diharapkan yaitu hasil belajar sehingga pengukuran gaya belajar lebih menitikberatkan pada bagaimana peserta didik memanfaatkan gaya belajarnya untuk mencapai hasil belajar yang tinggi sedangkan dalam penelitian ini menitikberatkan pada kecenderungan masing-masing peserta didik dalam belajar.

Berdasarkan uraian di atas, maka diperoleh kesimpulan bahwa peserta didik yang bergaya belajar visual memiliki model yang berbeda dengan peserta didik yang bergaya belajar auditorial dan kinestetik. Sehingga dapat disimpulkan bahwa ada perbedaan model pengaruh Gaya Belajar terhadap hasil belajar PAI Peserta didik kelas XI SMAN 1 Tinambung.

\section{Motivasi Berprestasi Terhadap Hasil Belajar PAI}

Motivasi Berprestasi berkaitan dengan dorongan yang dapat memungkinkan peserta didik untuk bertindak atau melakukan sesuatu. Dorongan itu hanya akan muncul dalam diri peserta didik manakala peserta didik merasa membutuhkan. Peserta didik yang merasa butuh akan bergerak dengan sendirinya untuk memenuhi kebutuhannya, oleh sebab itu, dalam rangka membangkitkan motivasi, guru harus dapat menunjukkan pentingnya pengalaman dan materi belajar bagi kehidupan peserta didik, dengan demikian peserta didikakan belajar bukan hanya sekedar untuk memperoleh nilai atau

${ }^{5}$ Alfarisi, " Pengaruh Gaya belajar, Motivasi dan Fasilitas belajar terhadap Hasil Belajar Mata Pelajaran Produktif. Program Studi Administrasi Perkantoran” e-Journal UM vol. 1 no. 1 (2016), h. 81

${ }^{6}$ Akhmad Sugyono, "Pengaruh Gaya terhadap Hasil Belajar Mata Pelajaran Akuntansi kalas XI IPS SMAN 3 Tapung” PeKA FKIP UIR vol. 6 no. 1 (2018), h. 8 
pujian akan tetapi didorong oleh keinginan untuk memenuhi kebutuhannya. Dengan demikian dapat dinyatakan Motivasi berprestasi yang baik belum tentu akan mendorong peserta didik untuk meraih prestasi belajar yang baik pula terkhusus pada mata pelajaran PAI.

\begin{tabular}{|l|c|c|c|}
\hline \multicolumn{1}{|c|}{ Variabel } & Koef.Regresi & $\begin{array}{c}\mathrm{t} \\
\text { hitung }\end{array}$ & Sig.t \\
\hline Konstanta & 60.281 & 6.745 & 0.000 \\
\hline $\begin{array}{l}\text { Motivasi } \\
\text { Berprestasi } \\
\text { X3) }\end{array}$ & 0,289 & 2.177 & 0.031 \\
\hline$R$ Square & 0,037 & & \\
\hline
\end{tabular}

Berdasarkan uji hipotesis, diperoleh fakta bahwa motivasi beprestasi tidak berpengaruh terhadap hasil belajar PAI peserta didik, hal ini ditunjukkan dengan hasil nilai signifikan sebesar 0,031 yang berarti lebih besar dari nilai signifikan 0,05 yang bermakna motivasi berprestasi tidak berpengaruh signifikan terhadap hasil belajar, dengan besar Koefisien derterminasi (pengaruh) $\mathrm{R}_{2}$ 0,037 yang berarti variable motivasi berprestasi memiliki pengaruh sebesar $3,7 \%$ terhadap hasil belajar peserta didik, pengaruh yang diberikan sangatlah kecil dan dan tidak signifikan maka hal ini berarti meskipun motivasi berprestasi peserta didik kelas XI SMAN Tinambung tergolong tinggi peserta didik masih saja belum memaksimalkan belajarnya untuk mencapai hasil belajar yang baik.

Hasil penelitian ini sejalan dengan penelitian yang dilakukan oleh Harlindah Syofyan, yang menujukkan bahwa tidak terdapat pengaruh Motivasi berprestasi terhadap hasl belajar IPA Mahasiswa PGSD Universitas Esa Unggul, dibuktikan dengan hasil pengujian hipotesis dengan menggunakan uji t regresi diperoleh harga $t$ Hitung $=(0,759)$ harga $t$ Table $=(1.659)$, sehingga $t$ hitung $<\mathrm{t}$ table. Dengan demikian hipotesis ditolak dan menyatakan bahwa tidak terdapat pengaruh yang positif dan signifikan variable motivasi berprestasi terhadap hasil belajar ${ }^{7}$ IPA mahasiswa PGSD Universitas Esa Unggul, tetapi setelah diuji secara simultan variabel gaya belajar dan motivasi berprestasi berpengaruh signifikan terhadap hasil belajar IPA mahasiswa PGSD Universitas Esa Unggul.

Hasil penelitian ini tidak sejalan dengan penelitian yang dilakukan oleh Cucu rusia ningsih dkk, bahwa terdapat hubungan yang positif dan signifikan antara motivasi berprestasi dengan hasil belajar matematika peserta didik kelas V Sekolah Dasar Negeri 16 Pontianak Kota. ${ }^{8}$ Hasil penelitian Tunjungsari Sekaringtyas menyatakan bahwa

\footnotetext{
${ }^{7}$ Harlindah Syofyan, “ Analisis Gaya Belajar dan Motivasi Berprestasi terhadap Hasil belajar IPA Mahasiswa PGSD Universitas Esa Unggul”'Eduscience vol.3 no.2 (2018)h.84

${ }^{8}$ Cucu Rusianingsih, dkk. , "Hubungan Motivasi Berprestasi, Minat dan Sikap dengan Hasil Belajar Matematika Kelas V Sekolah Dasar Negeri 16 Pontianak Kota” . (2016) h.7
} 
Motivasi Berprestasi mempengaruhi Hasil Belajar IPA, hal tersebut dapat dilihat dari hasil koefisien korelasi sebesar 0,641. Selain itu didapat juga nilai thitung sebesar 5,427 dimana tabel didapat 1,984723, maka t hitung $>$ t tabel yaitu 5,427 >1,984723 yang berarti Ho ditolak, artinya ada pengaruh yang signifikan antara Motivasi Berprestasi terhadap Hasil Belajar IPA9 .

Hasil penelitian Sriati Usman menunjukkan bahwa pembelajar yang memiliki motivasi berprestasi tinggi berbanding lurus memiliki hasil belajar yang tinggi demikian pula sebaliknya, hal ini dipengaruhi oleh metode pembelajaran yang baik. ${ }^{10}$.

\section{Pengaruh Kecerdasan Interpersonal, Motivasi Berprestasi, dan Gaya Belajar terhadap Hasil Belajar Peserta didik Kelas XI SMAN 1 Tinambung}

Hasil penelitian mendukung hipotesis keempat bahwa variabel kecerdasan interpersonal, gaya belajar, dan motivasi berprestasi berpengaruh positif bersama-sama terhadp hasil belajar hal ini ditunjukkan dengan hasil dari nilai $\mathrm{F}$ hitung sebesar 63.173 dengan $p$ value sebesar 0.000 .

Masing-masing variabel Kecerdasan Interpersonaal, Gaya belajar dan Motivasii berprestasi terhadap hasil belajar memiliki kadar atau besaran yang berbeda. Kecerdasan Interpersonal memiliki peran yang lebih besar dibanding Gaya Belajar dan Motivasi Berprestasi.

\section{V.SIMPULAN}

\section{A. Kesimpulan}

Gambaran Kecerdasan interpersonal peserta didik kelas XI SMA Negeri 1 Tinambung sebagaimana hasil analisis deskriptif berada pada kategori sangat tinggi. Sementara Gaya belajar peserta didik kelas XI SMAN 1 Tinambung setelah dilakukan pengukuran dengan menggunakan instrumen angket maka di dapatkan kesimpulan dari 126 peserta didik terbagi tiga gaya belajar, 33 peserta didik memiliki gaya belajar visual, 63 peserta didik memiliki gaya belajar auditorial, dan 30 lainnya memiliki gaya belajar kinestetik. Lain halnya dengan motivasi berprestasi peserta didik kelas XI SMAN 1 Tinambung sebagaimana hasil analisis deskriptif berada pada kategori sangat tinggi, Untuk Rata-rata hasil belajar PAI peserta didik kelas XI SMA Negeri 1 Tinambung sebagaimana hasil analisis deskriptif dapat disimpulkan bahwa Hasil belajar PAI peserta didik kelas XI SMAN 1 Tinambung berada pada kategori tinggi. Terdapat pengaruh signifikan kecerdasan interpersonal terhadap hasil belajar PAI peserta didik kelas XI SMAN 1 Tinambung, dengan koefisien derterminasi $\mathrm{R}_{2}$ sebesar 67,9\% hasil ini menujukkan bahwa semakin tinggi kecerdasan interpersonal maka hasil belajar akan

\footnotetext{
${ }^{9}$ Tunjungsari Sekartyas, “ Pengaruh Motivasi Berprestasi Dan Kemampuan Berpikir Kritis Terhadap Hasil Belajar IPA Siswa SD Sukatani IV “Jurnal Pendidikan Dasar (JPD). (2017) h. 167

${ }^{10}$ Sriati Usman,dkk. , “ Pengaruh Media Group Work Berbantuan Media Video dan Motivasi Berprestasi Terhadap Hasil Belajar Menulis Paragraft Deskriptif dalam Bahasa Inggris Mahasiswa Pendidikan Bahasa Inggris Universitas Tadulako" Jurnal Pendidikan Humaniora, vol. 3 no. 1,(2015). h.28
} 
semakin baik. Tidak Terdapat pengaruh signifikan antara motivasi berprestasi terhadap hasil belajar PAI peserta didik kelas XI SMA Negeri 1 Tinambung, dengan koefisien determinasi $\mathrm{R}_{2} 3,7 \%$. hal ini berarti pengaruh yang diberikan sangatlah kurang maka data disimpulkan bahwa meskipun motivasi berprestasi peserta didik kelas XI SMAN Tinambung tergolong tinggi peserta didik masih saja belum memaksimalkan belajarnya untuk mencapai hasil belajar yang baik. Terdapat perbedaan pengaruh dari gaya belajar peserta didik kelas XI SMAN 1 Tinambung, yaitu Terdapat pengaruh signifikan gaya belajar auditorial terhadap hasil belajar PAI peserta didik. Lain halnya dengan peserta didik yang memiliki gaya belajar visual dan kinestetik yang tidak memiliki pengaruh signifikan antara gaya belajar visual dan kinestetk terhadap hasil belajar PAI peserta didik kelas XI SMA Negeri1 Tinambung. Terdapat pengaruh signifikan secara simultan kecerdasan interpersonal, gaya belajar, dan motivasi berprestasi terhadap hasil belajar PAI peserta didik kelas XI SMAN 1 Tinambung dengan koefisien determinasi R2 62,7\% hal ini berarti bahwa terdapat pengaruh simultan dari seluruh variable bebas terhadap hasil belajar PAI Peserta didik Kelas XI SMAN 1 Tinambung.

\section{B. Saran}

Adapun beberapa saran yang dapat menjadi pertimbangan sebagai penyempurnaan berbagai hal yang berkaitan dengan penelitian ini, antara lain sebagai berikut. Bagi kepala sekolah, sebaiknya lebih memperhatikan faktor-faktor psikologis anak dalam belajar diantaranya kecerdasan interpersonal, dan motivasi berprestasi dalam proses pembelajaran PAI di kelas sehingga dapat berimplikasi pada peningkatan hasil belajar PAI peserta didik.

Bagi guru, diharapkan dapat menjadi masukan sehingga tidak hanya memperhatikan kemampuan akademik peserta didik dari aspek kognitif tetapi juga perlu memperhatikan aspek psikologis peserta didik di kelas agar proses dan hasil pembelajaran di kelas dapat mencapai tujuan secara maksimal dan optimal yakni tercapainya hasil belajar yanglebih baik. Hasil penelitian ini dapat dijadikan informasi bagi peserta didik tentang faktor-faktor yang berpengaruh terhadap hasil belajarnya, sehingga peserta didik dapat mengembangkan faktor-faktor yang ada untuk memaksimalkan belajarnya. Penelitian ini dapat menjadi masukan kepada orang tua/ wali untuk memperhatikan kemampuan kognitif peserta didik danf aktor-faktor psikologi yang dapat mempengaruhi hasil belajar PAI peserta didik. Bagi para peneliti yang berminat melakukan penelitian yang serupa, agar selain meneliti faktor-faktor yang ada dalam penelitian ini, juga meneliti tentang faktor-faktor lain yang juga mempengaruhi hasil belajar PAI peserta didik. Dan untuk penelitian selanjutnya khususnya yang tertarik dengan variabel penelitian ini perlu memperhatikan waktu, kondisi peserta didik dalam pengambilan data, jumlah item pernyataan yang akan diisi peserta didik dan menggunakan sampel yang lebih besar. Apabila ada variabel yang merupakan variabel kognitif,lebih baik diukur secara langsung atau diobservasi secara langsung pada saat proses pembelajaran berlangsung. 


\section{DAFTAR PUSTAKA}

Abdurrahmann, M. (2010). Pendidikan Bagi Anak Berkesulitan Belajar. Jakarta: Rineka Cipta

Alder, Harry, (2002). Boost Your Intelligence. Terj Cristina P., Jakarta: Erlangga.

Ali, Mohammad dan Asrori Mohammad. (2014). Psikologi Remajaa Perkembangan Peserta Didik. Jakarta: Bumi Aksara.

Alwisol. (2014). Psikologi Perkembangan.Edisi Revisi. Malang: UMM Press.

Amira Azzahra, 2018 "Pengruh kecerdasan interpersonal, Gaya Belajar, terhadap Hasil Belajar Matematika SMA di Kota Makasar. Tesis .Makassar: Universitas Negeri Makassar

Anas, A.\& Munir, N.P. (2016). Pengaruh Gaya Belajar VAK terhadap Hasil Belajar Matematika Siswa. Prosiding Seminar Nasional, (Online), 2(1), ISSN: 24431109,233-240, (journal.uncp.ac.id/index.php/proceding/article/vieew/392/352

Aunurrahman. (2009). Belajar dan Pembelajaran. Bandung: Alfabeta

A.M, Sardiman. (2014). Interaksi dan Motivasi Belajar Mengajar. Jakarta: Rajawali Pers.

Azwar, Syaifuddin. (2015). Skala Pengukuran Psikologi Pendidikan. Yogyakarta: Pustaka Belajar.

Azwaar.Syafuddin.( 2014). Metode Penelitian. Yogyakartaa: Pustaka Pelajarr.

Darmawan. (2013). Metode Penelitian Kuantitatif. Bandung: Remaja Rosdakarya.

Sriati Usman,dkk. (2015), “ Pengaruh Media Group Work Berbantuan Media Video dan Motivasi Berprestasi Terhadap Hasil Belajar Menulis Paragraf Deskriptif dalam Bahasa Inggris Mahasiswa Pendidikan Bahasa Inggris Universitas Tadulako" Jurnal Pendidikan Humaniora, vol. 3 no. 1

Fajriani, (2017) "Pengaruh Kecerdasan Interpersonal terhadap Hasil Belajar Matematika Peserta didik kelas X SMAN se- Kab. Bulukumba” Pedagogy vol. 2 no. 1.

Natalia Puspita Wulandari dkk, (2018) “ Pengaruh Kecerdasan Interpersonal, Kemampuan Berfikir dan Efikasi diri terhadap Hasil Belajar Matematika dan Sikap Terhadap Matematika Siswa Kelas VIII di Sekolah Menengah Pertama di Kota Makassar" Variansi UNM.

Najamuddin,(2015) “Pengaruh Kecerdasan Interpersonal dan Taks Commiment terhadap Hasil Belajar Siswa Kelas VIII MTSN Balang-balang Kab.Gowa” MaPan vol. 3 no. 2. 
Harlindah Syofyan, (2018) “Analisis Gaya Belajar dan Motivasi Berprestasi terhadap Hasil belajar IPA Mahasiswa PGSD Universitas Esa Unggul’Eduscience vol.3 no.2.

Cucu Rusianingsih, dkk.(2016), "Hubungan Motivasi Berprestasi, Minat dan Sikap dengan Hasil Belajar Matematika Kelas V Sekolah Dasar Negeri 16 Pontianak Kota”. 